\title{
Pengaruh Minat Baca dan Persepsi Atas Perpustakaan Sekolah terhadap Keterampilan Menulis Narasi
}

\author{
Hartinah, Suparman Ibrahim Abdullah \\ Fakultas Pascasarjana, Universitas Indraprasta PGRI \\ Jalan Nangka No. 58 C/TB. Simatupang, Tanjung Barat, Jakarta Selatan 12530
}

\begin{abstract}
This relates to analyzing simultaneous and partial interest in reading and school libraries on the ability to write narratives, especially junior high school students in the city of Tangerang. The research method used was a survey with regression and regression analysis, namely by linking data that shows interest in reading and perceptions of school libraries with data that shows students' writing ability in narration. Data about reading interest variables and school library perceptions were obtained through questionnaires. Data about the ability to write narration was obtained through a direct test by asking respondents to write a theme form/essay. From the results of the analysis of research data, it can be concluded that: (1) there is a significant influence of reading interest and perceptions of school libraries on the ability to write narratives of state junior high school students in the South Tangerang area, this is proven by Sig $=0,000<0.05$ and Fcount $=47,293$; (2) there is a significant tendency of reading interest towards the ability to write narration of State Junior High School students in the South Tangerang area, this is proven by Sig $=0,000<0.05$ and tcount $=4.898$; and (3) there is a significant influence of library perceptions on the ability to write state junior high schools in South Tangerang City, this is evidenced by Sig $=0,000<0.05$ and tcount $=4,532$.
\end{abstract}

Keywords: reading interest, the perception of the school library, narrative writing skills

\begin{abstract}
Abstrak
Hal ini bertujuan untuk menganalisis pengaruh minat membaca dan persepsi perpustakaan sekolah secara simultan dan parsial terhadap kemampuan menulis narasi, terutama siswa SMP di Kota Tangerang. Metode penelitian yang digunakan adalah survei dengan analisis korelasi dan regresi, yaitu dengan menghubungkan data yang menunjukkan minat membaca dan persepsi perpustakaan sekolah dengan data yang menunjukkan kemampuan menulis siswa dalam narasi. Data tentang variabel minat baca dan persepsi perpustakaan sekolah diperoleh melalui koesioner. Data tentang kemampuan menulis narasi diperoleh melalui tes langsung dengan meminta responden untuk membuat tulisan/ esai berbentuk tema. Dari hasil analisis data penelitian, dapat disimpulkan bahwa: (1) ada pengaruh yang signifikan minat baca dan persepsi perpustakaan sekolah terhadap kemampuan menulis narasi siswa SMP Negeri di daerah Tangerang Selatan, ini terbukti dengan Sig $=0,000<0,05$ dan Fcount $=47,293$; (2) ada pengaruh minat membaca yang signifikan terhadap kemampuan menulis narasi siswa SMP Negeri di wilayah Tangerang Selatan, hal ini dibuktikan oleh Sig $=0,000<0,05$ dan thitung = 4,898; dan (3) ada pengaruh signifikan persepsi perpustakaan sekolah terhadap kemampuan menulis SMP Negeri di Kota Tangerang Selatan, hal ini dibuktikan oleh Sig $=0,000<0,05$ dan tcount $=4,532$.
\end{abstract}

Kata Kunci: minat baca, persepsi atas perpustakaan sekolah, keterampilan menulis narasi

\section{PENDAHULUAN}

Bahasa Indonesia sebagai bahasa nasional, diajarkan di setiap jenjang pendidikan sekolah dari sekolah dasar sampai ke perguruan tinggi. Tujuan pengajaran bahasa Indonesia tersebut bervariasi bergantung pada jenjang pendidikannya. Namun,

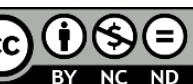

Creative Commons Attribution-NonCommercial-NoDerivatives 4.0 International License 
secara umum tujuan pengajaran bahasa Indonesia di sekolah antara lain untuk mengembangkan kemampuan pelajar terkait keterampilan berbahasa dalam empat aspek, yaitu (1) keterampilan menyimak atau mendengarkan, (2) keterampilan berbicara, (3) keterampilan membaca, dan (4) keterampilan menulis.

Bidang pengajaran bahasa, membagi bahasa dalam dua aspek pengajaran, yaitu pengajaran kemampuan berbahasa dan pengajaran kemampuan bersastra. Kompetensi menulis dalam pengajaran berbahasa dan bersastra adalah tataran yang tersulit dibanding tiga kompetensi lainnya, yaitu mendengarkan, membaca, dan berbicara. Hal ini dikarenakan menulis memerlukan keterampilan berpikir logis dan bernalar Oleh karena itu, para guru dituntut untuk mengajarkan kompetensi kebahasaan dan kesastraan dengan mempertimbangkan kepaduan.

Keberhasilan seorang guru membimbing siswa sehingga mampu menulis yang baik dapat dijadikan tolok ukur keberhasilan dalam mengajar kebahasaan dan kesastraan. Ketidakberhasilan pengajaran menulis di tingkat SLTP dipengaruhi banyak factor, di antaranya faktor tenaga pengajar, pelajar (siswa), sarana pembelajaran, dan sistem pembelajaran. Kemampuan menulis siswa rendah antara lain disebabkan juga oleh belum terlaksananya hakikat pembelajaran menulis. Proses belajar mengajar menulis pada semua jenjang pendidikan ternyata lebih banyak berpusat pada segala sesuatu tentang menulis. Siswa lebih banyak mendapat teori-teori tentang format, tata cara, dan kaidah-kaidah penulisan.

Khusus dalam pembelajaran bahasa, faktor internal non-akademis yang sangat diperlukan adalah minat baca. Minat baca sangat diperlukan untuk mengembangkan pengetahuan dan wawasan siswa, serta meningkatkan kemampuan dalam memahami isi bacaan. Minat baca yang tinggi dalam diri siswa tinggi senantiasa mengisi waktu luang dengan membaca. Kurangnya minat baca dari para siswa SMP merupakan fenomena. Jika minat baca merupakan salah satu faktor internal yang dapat memengaruhi prestasi belajar bahasa Inggris, maka salah satu faktor eksternal yang tidak kalah pentingnya dalam mempengaruhi prestasi belajar bahasa Inggris adalah faktor kelengkapan sarana belajar.

Di sekolah, sarana belajar yang berupa perbukuan atau sumber-sumber belajar yang lain biasanya dikelola oleh perpustakaan sekolah. Keberadaan perpustakaan sangat dibutuhkan sebagai penunjang pembelajaran. Tersedianya perpustakaan sekolah bergantung kemempuan pemerintah untuk membangunnya. Selama ini pemerintah baru fokus membangun sarana perpustakaan untuk sekolah negeri, sedangkan sekolah swasta untuk membangun gedung perpustakaan sekolah dengan menggunakan biaya sendiri.

Mutu pendidikan yang baik terpengaruh besar oleh adanya perpustakaan. Perpustakaan sekolah tidak akan ada artinya apabila siswa yang berada dalam lingkup sekolah tersebut tidak memanfaatkan sarana yang ada. Untuk itu, diperlukan pendapat yang positif terhadap perpustakaan sekolah sehingga menumbuhkan kesadaran dari generasi muda, khususnya siswa atau peserta didik untuk memanfaatkannya semaksimal mungkin. Selama ini persepsi siswa atas penggunaan perpustakaan sekolah adalah tempat tumpukan buku-buku atau gudang buku yang hanya didatangi apabila siswa disuruh meminjam buku pelajaran, padahal sebenarnya perpustakaan sekolah tidak hanya tempat tumpukan buku-buku 
saja, maknanya lebih dari itu. Perpustakaan sekolah adalah salah satu bagian dari sarana pendidikan yang ikut berperan dalam memperluas wawasan siswa.

Dari beberapa uraian di atas, penulis berpendapat bahwa faktor minat membaca dan persepsi siswa atas perpustakaan sekolah yang dimiliki siswa ada hubungannya dengan kemampuan siswa dalam menulis, termasuk pula dalam menulis narasi. Oleh karena itu, penulis tertarik untuk meneliti lebih lanjut tentang pengaruh minat baca dan motivasi belajar terhadap kemampuan menulis narasi siswa SMP Negeri di Kota Tangerang.

\section{Minat Baca}

Menurut Guilford dalam (Sutjipto, 2001), ketertarikannya seseorang pada jenis kegiatan tertentu berdasarkan minat untuk berperilaku. Menurut (Ahmadi, 2003) minat adalah mengacu pada ketiga fungsi jiwa (kognisi, konasi, emosi) dengan melibat perasaan yang sangat kuat. Menurut (Slameto, 2003) minat merupakan rasa suka atau tertarik terhadap suatu aktivitas atau kegiatan tanpa ada unsur paksaan. Pada dasarnya, minat merupakan berterimanya antara diri sendiri dengan dunia luar. Semakin kuat hubungan tersebut, semakin kuat minat.

Membaca berasal dari kata dasar baca yang berarti mengeja. Membaca dapat diartikan bahwa proses melihat dan memahami sebuah tulisan dengan cara mengeja dan melafalkan (Badan Pengembangan dan Pembinaan Bahasa, 2016). Dari pengertian di atas nampaknya yang sesuai dengan konteks pembahasan dalam hal ini adalah pengertian yang pertama, karena dalam pembahasan di sini lebih mengarah pada pengertian membaca dalam proses pembelajaran, sehingga membaca dalam belajar lebih diutamakan untuk memahami isi dari apa yang dibaca.

Menurut (Farris, 2005), membaca merupakan suatu proses terhadap katakata, konsep, informasi, dan gagasan-gagasan dari pengarang dan pengalaman pembaca dalam menyerap pengetahuan. Dengan demikian, berdasarkan pengalam membaca, seseorang akan dapat memahami apa yang dibacanya.

Makna dari sebuah tulisan dapat ditemukan dari proses fisik dan mental yang disebut membaca. Fisik, karena melibat bagian tubuh, yaitu mata. Mental, karena melibatkan pikiran, khususnya ingatan dan pemahaman Dikatakan kegiatan mental karena bagian-bagian pikiran khususnya persepsi. Jadi, membaca bertujuan untuk menemukan makna dari tulisan bukan sekadar mengenali hurf (Tampubolon, 2003).

Dari pengertian di atas dapat disimpulkan bahwa minat baca adalah sesuatu yang dapat membangkitkan atau mendorong seseorang untuk menjadi rajin membaca dan selalu berusaha untuk mengetahui suatu yang ada di setiap bahan bacaan yang dia temukan. Dengan begitu, akan lahir perhatian, konsentrasi, memperkuat ingatan, dan kebosanan dalam belajar.

\section{Persepsi Siswa Atas Penggunaan Perpustakaan Sekolah}

Menurut (Darmono, 2007), perpustakaan adalah unit kerja yang bertugas untuk mengelola bahan-bahan pustaka, baik berupa buku-buku maupun bukan berupa buku-buku (nonbook material) yang diukur secara sistematis menurut aturan-aturan tertentu yang pada nantinya dapat dipergunakan sebagai sumber informasi. 
Menurut (Umar, 2002), perpustakaan merupakan sebuah ruangan bagian dari sebuah gedung untuk menyimpan buku atau pustaka lainnya yang disusun sesuai aturan dan tidak untuk dijual meliputi buku, majalah, laporan, pamflet, prosiding, manuskrip (naskah), lembaran dan karya musik, audiovisual, slid (slide), kaset, piringan hitam, mikrofilm, mikrofis, dan mikroburam (microopaque).

Menurut (Soetminah, 1997), perpustakaan adalah penyedia sarana berupa bahan bacaan. Khusus untuk perpustakaan di perguruan tinggi, perpustakaan merupakan layanan untuk kegiatan pengajaran, penelitian, dan abdimas dalam rangka melaksanakan Tri Dharma Perguruan Tinggi, sedangkan dalam Pasal 1 Undang-undang RI No. 43 Tahun 2007 dijelaskan bahwa perpustakaan adalah institusi pengelola koleksi karya tulis, karya cetak, dan/ atau karya rekam secara profesional dengan sistem yang baku guna memenuhi kebutuhan pendidikan, penelitian, pelestarian, informasi, dan rekreasi para pemustaka.

Menurut (Yusuf \& Suhendar, 2007) mengatakan bahwa fungsi perpustakaan di sekolah adalah sebagai berikut: 1) Memantapkan pengetahuan; 2) Memupuk gemar membaca, meneliti, dan mengembangkan pengetahuan. Hal itu juga sejajar dengan fungsi perpustakaan kecil di rumah. Kebanyakan orang tua meskipun mempunyai rumah berukuran besar, tidak sedikitpun terpikir untuk membuat perpustakaan kecil agar anaknya belajar dengan nyaman dan penuh motivasi.

Perpustakaan adalah bagian dari sarana belajar. Dalam proses belajar mengajar sarana bukan hanya sebagai pelengkap semata-mata, tetapi mempunyai peranan, antara lain (1) sebagai unsur pencapai tujuan, (2) sebagai pengembang kemampuan, (3) sebagai katalisator dalam proses pemahaman materi, dan (4) sebagai pembawa informasi. Pernanfaatan perpustakaan adalah aktivitas siswa untuk menggunakan sarana-sarana belajar yang telah tersedia dengan sebaikbaiknya guna meningkatkan prestasi belajarnya. Pemanfaatan perpustakaan dapat berupa usaha siswa untuk membaca buku-buku perpustakaan, majalah, dan surat kabar yang berisi pelajaran Bahasa Indonesia. Tersedianya perpustakaan di sekolah dipengaruhi juga oleh keadaan ekonomi siswa yang bersekolah di sekolah tersebut. Keadaan ekonomi orang tua siswa yang mampu memungkinkan tersedianya perpustakaan yang memadai untuk siswa tersebut. Untuk mencapai prestasi belajar Bahasa Indnesia yang baik, dibutuhkan sarana belajar seperti perpustakaan yang memadai, buku pelajaran, serta fasilitas belajar lainnya. Mengelola perpustakaan ini bukan hanya menjalankan rutinitas sekolah sehari-hari, tetapi dapat menentukan strategi yang efektif bagi sekolah dalam hal menjalankan kebijakan perpustakaan dan pengembangannya, pemilihan koleksi buku, pengorganisasian koleksi perpustakaan, meningkatkan kecakapan siswa menjadi pembaca yang efektif, dan mengembangkan keterampilan riset siswa dan keterampilan lainnya. Berdasarkan semua uraian di atas maka dapat dibuat sintesis bahwa pengertian dari persepsi siswa atas penggunaan perpustakaan sekolah adalah penilaian atau tanggapan siswa tentang segala sesuatu yang ia ketahui dan pahami tentang perpustakaan sekolah yang meliputi sarana fisik bangunan, prasarana penunjang, koleksi/ isi yang ada, pengaturan/penyusunan ruangan, sampai pada tata kelola pemanfaatan isi perpustakaan untuk menunjang proses pembelajaran. 


\section{Keterampilan Menulis Narasi}

Menurut (Dunnette, 2001), keterampilan merupakan kapasitas yang dibutuhkan untuk melaksanakan tugas. Kerampilan merupakan pengembangan hasil training dan pengalaman yang didapat. Menurut (Iverson, 2001) selain training, keterampilan juga membutuhkan kemampuan dasar (basic ability) untuk melakukan pekerjaan secara mudah dan tepat. Menurut (Dryden \& Vos, 2004), keterampilan merupakan kemampuan mengoperasikan pekerjaan yang dilakukan secara mudah dan cermat (aktivitas psikomotor).

Menurut (Pranoto, 2004), menulis adalah penuangan buah pikiran ke dalam bentuk tulis atau menceritakan sesuatu kepada orang lain melalui tulisan. Menulis juga dapat diartikan sebagai ungkapan atau ekspresi perasaan yang dituangkan dalam bentuk tulisan. Dengan kata lain, melalui proses menulis kita dapat berkomunikasi secara tidak langsung. Gambar atau lukisan mungkin dapat menyampaikan makna-makna, tetapi tidak menggambarkan kesatuan-kesatuan bahasa. Menulis merupakan suatu representasi bagian dari kesatuan-kesatuan ekspresi bahasa. Hal ini merupakan perbedaan utama antara lukisan dan tulisan, antara melukis dan menulis.

Menulis merupakan bentuk pikiran, angan-angan, dan perasaan yang dilambangkan, ditandakan, dan ditulisankan. Lebih lanjut dikatakan bahwa menulis merupakan kegiatan pengungkapan gagasan tertulis yang berbeda dengan kegiatan pengungkapan gagasan secara lisan (Suhendar, 2002). Menurut (Hernowo, 2002) menulis ditinjau dari segi bahasa, membuat huruf, angka, dan sebagainya dengan pena (pensil, kapur, dan sebagainya) atau bisa juga diartikan melahirkan pikiran atau perasaan (seperti mengarang, membuar surat) dengan tulisan.

Adapun untuk pengertian narasi, menurut (Suhendar, 2002), karangan narasi merupakan suatu bentuk wacana yang berusaha mengisahkan suatu kejadian atau penstiwa, sehingga tampak seolah-olah pembaca melihat atau mengalami penstiwa itu. Selain itu, (Djuherli \& Suherli, 2001) menyatakan bahwa narasi adalah karangan yang mengisahkan suatu peristiwa yang disusun secara kronologis dengan tujuan memperluas pengalaman seseorang.

Menurut (Keraf, 2007), narasi adalah sebuah bentuk wacana yang sasaran utamanya adalah tindak-tanduk yang dijalin dan dirangkaikan menjadi sebuah peristiwa yang terjalin dalam satu kesatuan. Atau narasi adalah suatu bentuk wacana yang berusaha menggambarkan dengan sejelas-jelasnya kepada pembaca mengenai suatu peristiwa yang telah terjadi. Pendapat lain bahwa karangan narasi adalah karangan yang menceritakan suatu peristiwa atau kejadian dengan tujuan agar pembaca seolah-olah mengalami kejadian yang diceritakan itu (Kosasih, 2008).

Hal senada diungkapkan oleh (Rusyana, 2008), ia menyebutkan bahwa karangan narasi adalah karangan kisahan yang isinya memaparkan terjadinya peristiwa, baik peristiwa kenyataan maupun peristiwa rekaan. Berkenaan dengan peristiwa itu dipaparkan siapa yang menjadi pelakunya, di mana tempat terjadinya, bagaimana suasana terjadinya, dan siapa juru kuncinya.

Berdasarkan beberapa pengertian karangan narasi di atas, dapat disimpulkan bahwa karangan narasi adalah karangan yang menceritakan suatu peristiwa atau kejadian yang mengandung unsur-unsur pelaku, konflik, tindakan, ruang, dan

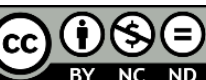

Creative Commons Attribution-NonCommercial-NoDerivatives 4.0 International License 
waktu yang dijalin dan dirangkaikan menjadi sebuah peristiwa sehingga membentuk sebuah alur cerita agar pembaca merasa seolah-olah mengalami kejadian yang diceritakan itu. Dari semua hasil kajian teori tersebut, maka penulis menyimpulkan bahwa keterampilan menulis narasi yang dimaksud dalam penelitian ini adalah kecakapan atau kemampuan dalam melaksanakan aktivitas berbahasa yang dipergunakan untuk berkomunikasi melalui suatu bentuk wacana untuk menggambarkan dengan sejelas-jelasnya kepada pembaca tentang suatu peristiwa yang terjadi.

\section{METODE}

Penelitian ini termasuk dalam jenis penelitian eksplanatari dengan pendekatan kuantitatif, dan teknik analisis data serta pengujian hipotesisnya dengan menggunakan teknik analisi korelasi dan regresi sederhana tunggal dan berganda. Populasi penelitian ini adalah siswa kelas VIII SMP Negeri di Kota Tangerang tahun pelajaran 2017/2018 yang dibatasi pada siswa kelas VIII SMP Negeri 1 Kota Tangerang, SMP Negeri 2 Kota Tangerang, dan SMP Negeri 3 Kota Tangerang tahun pelajaran 2017/2018. Jumlah anggota sampel ditentukan dengan menggunakan rumus Slovin sehingga diperoleh sampel dengan anggota sebanyak 60 orang siswa. Untuk teknik pemilihan sampel digunakan gabungan dari teknik cluster, proporsional, dan acak.

Alat ukur untuk menentukan nilai dari setiap variable menggunakan instrumen. Pada penelitian ini, instrumen yang dimaksud adalah angket. Angket meliputi minat baca, persepsi siswa pada perpustakaan sekolah, dan kriteria menulis (hasil menulis siswa).

\section{HASIL DAN PEMBAHASAN}

\section{Hasil}

Analisis data baik yang terkait dengan penyajian data, pengujian persyaratan data, maupun yang terkait dengan pengujian hipotesis dilakukan dengan bantuan program aplikasi SPSS versi 24. Hasil-hasil yang terkait dengan pengujian hipotesis adalah berikut:

Tabel 2. Hasil Perhitungan Koefisien Korelasi Berganda Pengaruh Variabel $X_{1}, X_{2}$, dan $X_{3}$ terhadap Variabel $Y$

Model Summary ${ }^{b}$

\begin{tabular}{|c|c|c|c|c|}
\hline Mo-del & $\mathrm{R}$ & $\mathrm{R}$ Square & $\begin{array}{c}\text { Adjusted R } \\
\text { Square }\end{array}$ & $\begin{array}{c}\text { Std. Error of the } \\
\text { Estimate }\end{array}$ \\
\hline 1 & $774^{\mathrm{a}}$ & .598 & .584 & 5.00107 \\
\hline
\end{tabular}

a. Predictors: (Constant), Persepsi_Atas_Perpustakaan_Sekolah, Minat_Baca

b. Dependent Variable: Keterampilan_Menulis_Narasi 
Tabel 3. Hasil Perhitungan Persamaan Garis Regresi Berganda dan Analisis Pengaruh Partial Variabel $X_{1}, X_{2}$, dan $X_{3}$ terhadap Variabel $Y$ Coefficients $^{\mathbf{a}}$

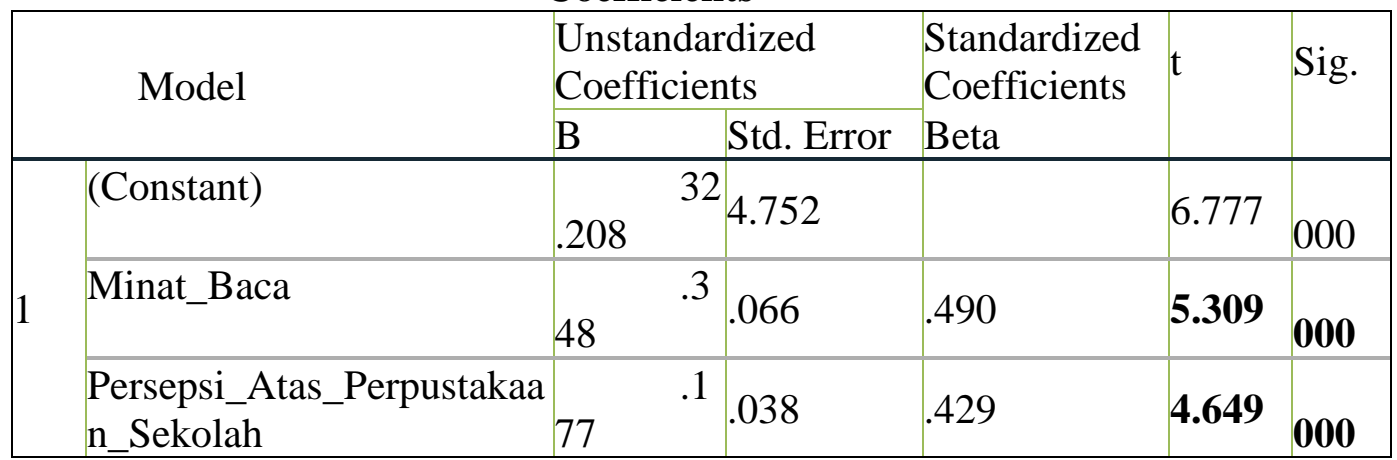

a. Dependent Variable: Keterampilan_Menulis_Narasi

Tabel 4. Rekapitulasi Hasil Perhitungan Pengujian Signifikasi Koefisien Regresi Pengaruh Simultan Variabel $X_{1}, X_{2}$, dan $X_{3}$ terhadap Variabel $Y$ ANOVA ${ }^{a}$

\begin{tabular}{|c|l|c|l|l|l|l|}
\hline \multicolumn{2}{|c|}{ Model } & Sum of Squares & df & Mean Square & F & Sig. \\
\hline \multirow{4}{*}{1} & Regression & 2124.126 & & 1062.063 & $\mathbf{4 2 . 4 6 4}$ & $\mathbf{. 0 0 0}^{\mathbf{b}}$ \\
\cline { 2 - 8 } & Residual & 1425.607 & 7 & 25.011 & & \\
\cline { 2 - 8 } & Total & 3549.733 & 9 & & & \\
\hline
\end{tabular}

a. Dependent Variable: Keterampilan_Menulis_Narasi

b. Predictors: (Constant), Persepsi_Atas_Perpustakaan_Sekolah, Minat_Baca

\section{Pembahasan}

Pengaruh minat baca dan persepsi siswa pada perpustakaan sekolah secara bersama-sama terhadap keterampilan menulis narasi

Dari analisis korelasi diperoleh koefisien korelasi berganda pengaruh variabel bebas minat baca $\left(\mathrm{X}_{1}\right)$ dan persepsi siswa pada perpustakaan sekolah $\left(\mathrm{X}_{2}\right)$ secara bersama-sama terhadap keterampilan menulis narasi (Y) adalah sebesar 0,774. Dari hasil pengujian diperoleh bahwa koefisien korelasi tersebut signifikan, dengan kata lain bahwa terdapat pengaruh yang signifikan variabel bebas minat baca $\left(\mathrm{X}_{1}\right)$ dan persepsi siswa pada perpustakaan sekolah $\left(\mathrm{X}_{2}\right)$ secara bersama-sama terhadap keterampilan menulis narasi (Y).

Untuk koefisien determinasinya adalah sebesar 59,8\% menunjukkan bahwa besarnya kontribusi minat baca dan persepsi siswa pada perpustakaan sekolah secara bersama-sama terhadap keterampilan menulis narasi adalah sebesar 59,8\%, sisanya $(40,2 \%)$ karena pengaruh faktor lain yang tidak diteliti.

Untuk pengujian hipotesis melalui analisis regresi diperoleh hasil perhitungan terlihat pada Tabel 3 dan Tabel 4. Dari Tabel 3 diperoleh persamaan garis regresi yang merepresentasikan pengaruh variabel $\mathrm{X}_{1}$ dan $\mathrm{X}_{2}$ terdahap variabel Y, yaitu $\widehat{\mathbf{Y}}=32,208+0,348 \mathrm{X}_{\mathbf{1}}+0,177 \mathrm{X}_{\mathbf{2}}$. Nilai konstanta $=32,208$ menunjukkan bahwa dengan minat baca dan persepsi siswa pada perpustakaan sekolah siswa 
paling rendah sulit bagi siswa tersebut untuk bisa meraih pretasi belajar yang baik, sedangkan nilai koefisien regresi sebesar 0,348 dan 0,177 menunjukkan bahwa terdapat pengaruh positif variabel bebas $X_{1}$ (minat baca) dan $X_{2}$ (persepsi siswa pada perpustakaan sekolah) secara bersama-sama terhadap variabel terikat $\mathrm{Y}$ (keterampilan menulis narasi). Angka koefisien regresi tersebut juga menunjukkan bahwa setiap ada kenaikan satu satuan nilai pada variabel minat baca maka akan terdapat kenaikan pada variabel keterampilan menulis narasi sebesar 0,348 satuan, dan setiap ada kenaikan satu satuan nilai pada variabel persepsi siswa pada perpustakaan sekolah siswa, maka akan terdapat kenaikan pada variabel keterampilan menulis narasi sebesar 0,177 satuan.

Setelah dilakukan pengujian, diperoleh bahwa nilai $\mathbf{S i g}=0.000<0,05$ dan $\mathbf{F}_{\text {hitung }}=42,464$, maka $\mathrm{H}_{0}$ ditolak dan $\mathrm{H}_{1}$ diterima yang berarti bahwa regresi tersebut signifikan. Hal itu menunjukkan bahwa memang terdapat pengaruh yang signifikan minat baca $\left(\mathrm{X}_{1}\right)$ dan persepsi siswa pada perpustakaan sekolah $\left(\mathrm{X}_{2}\right)$ secara bersama-sama terhadap keterampilan menulis narasi (Y).

\section{Pengaruh minat baca terhadap keterampilan menulis narasi}

Dari tabel Coefficients ${ }^{\text {a }}$ di atas, pada baris Minat_Baca diperoleh bahwa nilai Sig $=0,000<0,05$ dan thitung $=5,309$ maka $\mathrm{H}_{0}$ ditolak dan $\mathrm{H}_{1}$ diterima yang berarti terdapat pengaruh yang signifikan minat baca terhadap keterampilan menulis narasi.

\section{Pengaruh persepsi siswa pada perpustakaan sekolah terhadap keterampilan menulis narasi}

Dari tabel Coefficients ${ }^{\mathbf{a}}$ di atas, pada baris Persepsi_Siswa_Pada_Perpustakaan_ Sekolah diperoleh bahwa nilai $\mathbf{S i g}=0,000<0,05$ dan thitung $=4,649$ maka $\mathrm{H}_{0}$ ditolak dan $\mathrm{H}_{1}$ diterima yang berarti terdapat pengaruh yang signifikan persepsi siswa pada perpustakaan sekolah terhadap keterampilan menulis narasi.

\section{SIMPULAN}

Berdasarkan hasil penelitian maka dapat disimpulkan bahwa:

1. Terdapat pengaruh yang signifikan minat baca dan persepsi atas perpustakaan sekolah secara bersama-sama terhadap keterampilan menulis narasi siswa SMP Negeri di kota Tangerang. Hal ini dibuktikan oleh nilai Sig $=0,000<0,05$ dan $\mathbf{F}_{\text {hitung }}=42,464$.

2. Terdapat pengaruh yang signifikan minat baca terhadap keterampilan menulis narasi siswa SMP Negeri di kota Tangerang. Hal ini dibuktikan oleh nilai Sig = $0,000<0,05$ dan thitung $=5,309$.

3. Terdapat pengaruh yang signifikan persepsi atas perpustakaan sekolah terhadap keterampilan menulis narasi siswa SMP Negeri di kota Tangerang. Hal ini dibuktikan oleh nilai $\mathbf{S i g}=0,000<0,05$ dan $\mathbf{t}_{\text {hitung }}=4,649$.

\section{DAFTAR PUSTAKA}

Ahmadi, A. (2003). Psikologi belajar (Cetakan ke). Jakarta: Rineka Cipta. 
Badan Pengembangan dan Pembinaan Bahasa. (2016). Kamus Besar Bahasa Indonesia. Jakarta: Badan Pengembangan dan Pembinaan Bahasa.

Darmono. (2007). Perpustakaan sekolah: Pendekatan suatu aspek manajemen dan tata kerja. Jakarta: Gramedia Widiasmara Indonesia.

Djuherli, \& Suherli. (2001). Telaah wacana: Teori dan penerapannya. Depok: Komodo Books.

Dryden, G., \& Vos, J. (2004). Revolusi cara belajar. Bandung: Kaifa.

Dunnette, G. (2001). History of educational thought. New York: American Book Company.

Farris, H. (2005). Active learning, 101 cara belajar siswa aktif. Bandung: Nusamedia.

Hernowo. (2002). Memupuk bakat dan kreativitas siswa sekolah menengah. Jakarta: Gramedia Pustaka Utama.

Iverson, T. (2001). Learning principles and application. Singapore: Mc Grow Hill.

Keraf, G. (2007). Komposisi sebuah pengantar kemahiran berbahasa. Flores: Nusa Indah.

Kosasih, E. (2008). Kumpulan istilah dan apresiasi sastra bahasa Indonesia. Surabaya.

Pranoto, J. (2004). Menulis efektif. Bandung: Angkasa Raya.

Rusyana. (2008). Keterampilan dasar menulis. Jakarta: Universitas Terbuka.

Slameto. (2003). Belajar dan faktor-faktor yang mempengaruhinya. Jakarta: Rineka Cipta.

Soetminah. (1997). Perpustakaan kepustaka-wanan dan Pustakawan. Yogyakarta: Kanisius.

Suhendar. (2002). Panduan efektif belajar menulis. Bandung: Angkasa.

Sutjipto. (2001). Pengembangan sistem evaluasi. Yogyakarta: Insan Madani.

Tampubolon, H. (2003). Strategi pengajaran bahasa dan sastra Indonesia. Surakarta: Yuma Pustaka.

Umar, H. (2002). Evaluasi kinerja perpustakaan. Jakarta: Gramedia Pustaka Utama.

Yusuf, P. M., \& Suhendar, Y. (2007). Pedoman penyelenggaraan perpustakaan sekolah. Jakarta: Kencana Prenada Media. 